\title{
Notes on Contributors April 2011
}

\author{
Abigail L. Rosenthal
}

Abigail L. Rosenthal wrote $A$ Good Look at Evil (Temple University Press, 1987) and Conversions: A Philosophic Memoir (Temple University Press, 1995) and edited The Consolations of Philosophy: Hobbes' Secret; Spinoza's Way by H.M. Rosenthal (Temple University Press, 1989). This article is adapted from her next book, Terror and Evil.

\section{Hallvard Lillehammer}

Hallvard Lillehammer teaches moral and political philosophy at Cambridge University, where he is a University Senior Lecturer, the Sidgwick lecturer and a Senior Research Fellow at Churchill College. He is the author of Companions in Guilt: Arguments for Ethical Objectivity (Palgrave Macmillan, 2007).

\section{N.M.L. Nathan}

N.M.L. Nathan is an Honorary Senior Fellow at the Universities of Liverpool and Birmingham. He is the author of Will and World (Oxford University Press, 1992) and The Price of Doubt (Routledge, 2000).

\section{William Lane Craig}

William Lane Craig is Research Professor of Philosophy at Talbot School of Theology in La Mirada, California. He is the co-editor with Quentin Smith of Einstein, Relativity, and Absolute Simultaneity (Routledge, 2007) and with J. P. Moreland of The Blackwell Companion to Natural Theology (Wiley-Blackwell, 2009). Research interests include topics in metaphysics, philosophy of time, and philosophy of religion. He is currently exploring the relationship between God and abstract objects.

\section{Roy Sorensen}

Roy Sorensen is Professor of Philosophy at Washington University in St. Louis. He is the author of Seeing Dark Things: The Philosophy of Shadows (Oxford University Press, 


\section{Notes on Contributors}

2008), A Brief History of the Paradox (Oxford University Press, 2005), Thought Experiments (Oxford University Press, 1999), Pseudo-Problems (Routledge, 1993) and Blindspots (Oxford University Press, 1988).

Christopher Miles Coope

Christopher Miles Coope has published two related articles, 'Good Bye to the Problem of Evil, Hello to the Problem of Veracity', Religious Studies, 2001, and 'Dodgy Passport, Fruitless Journey', Philosophy, October, 2008. 